\title{
Intravenous lipoma and pulmonary sarcoidosis treated with prednisone
}

\section{Lipoma intravenoso y sarcoidosis pulmonar tratada con prednisona}

\author{
L.A.M. Santos ${ }^{1}$, V.M. Santos ${ }^{2}$, D.N. Pitol ${ }^{1}$, D.F. Duailibi ${ }^{1}$
}

\begin{abstract}
Corticosteroid-induced lipomatosis is not a rare condition, but lipoma in the central veins has scarcely been described. According to the databases consulted, this is the first report of a lipoma within the central veins coexistent with long-term use of corticosteroid. It involved a 47-year-old male under treatment for pulmonary sarcoidosis with prednisone. Computerized tomography of the thorax was performed and incidentally the images showed a mass within the central veins with the characteristics of lipoma. He was asymptomatic and refused surgical procedures. The intraluminal lipoma originated in the right brachiocephalic and subclavian veins. Control tomography showed a slow development of this lipoma, without obstructive effects or malignant features. Oral prednisone was changed for methotrexate. The patient is asymptomatic and under longstanding out-patient surveillance. Corticosteroid treatments for sarcoidosis can play a role in the development of intravascular lipoma, but this association is not well defined. Case reports could contribute to clarifying whether this relationship is causal or merely casual.
\end{abstract}

Key words. Corticosteroid. Intravascular lipoma. Sarcoidosis. Brachiocephalic vein. Subclavian vein.

\section{RESUMEN}

La lipomatosis inducida por glucocorticoides no es una entidad rara, pero hay pocos casos descritos de lipoma en las venas centrales. Según la bibliografía, éste es el primer trabajo de un paciente con un lipoma en las venas centrales coexistente con el uso de glucocorticoide a largo plazo. Se trata de un hombre de 47 años, en tratamiento de sarcoidosis pulmonar con prednisona. Se realizó tomografía computarizada de tórax e incidentalmente, las imágenes mostraron una masa en las venas centrales, con características de lipoma. El paciente estaba asintomático y se negó a la realización del procedimiento quirúrgico. Este lipoma intraluminal se originó en la vena braquiocefálica y subclavia derecha. El estudio tomográfico demostró un desarrollo lento del lipoma, sin efectos obstructivos ni características malignas. La prednisona oral se cambió por metotrexate. El paciente permanece asintomático, realizando un seguimiento ambulatorio. Los tratamientos con glucocorticoides para sarcoidosis pueden desempeñar un papel importante en el desarrollo de lipomas intravasculares, pero esta asociación no está bien definida. Se desconoce si la relación de esta asociación es causal o meramente casual.

Palabras clave. Glucocorticoides. Lipoma intravascular. Sarcoidosis. Vena braquiocefálica. Vena subclavia.
1. Surgery Department from State Workers Hospital (HSE). São Paulo-SP. Brazil.

2. Catholic University (UCB) and Internal Medicine Department from Armed Forces Hospital (HFA). Brasília-DF. Brazil.

Recepción: 6 de enero de 2012

Aceptación provisional: 8 de febrero de 2012

Aceptación definitiva: 22 de febrero de 2012

\section{Corresponding:}

Vitorino Modesto dos Santos

Armed Forces Hospital

Estrada do Contorno do Bosque $\mathbf{s} / \mathrm{n}$

Cruzeiro Novo, 70658-900 Brasília-DF. Brazil

E-mail: vitorinomodestos@gmail.com 


\section{INTRODUCTION}

Sarcoidosis is an autoimmune disease with diverse clinical presentations and unknown etiology ${ }^{1,2}$. Diagnosis is based on clinical features, imaging data, and histological demonstration of noncaseating epithelioid-cell granulomas and absence of microorganisms or particles in biopsy samples $^{1,2}$. Corticosteroids constitute the first choice therapy for lung sarcoidosis, and corticosteroid-sparing drugs are indicated for patients presenting with severe side effects $^{1,2}$. Development of lipomas may be secondary to corticotherapy; and Montoriol et al first described steroid-induced intradural lipomas in a 29-year-old man with systemic sarcoidosis ${ }^{3}$. Intravenous lipoma is a rare tumor, which usually evolves asymptomatic and is incidentally detected during routine computed tomography or magnetic resonance studies ${ }^{4-10}$. Patients with symptomatic intravenous lipomas may present with indicative signs of vascular occlusion ${ }^{11}$. The present case study is about a 47-year-old-man with an unsuspected intravenous lipoma. Short literature review of the data from eight cases of lipoma within the superior vena cava and brachiocephalic or subclavian veins was done in order to compare the main features ${ }^{4-11}$. The association with corticotherapy was not described in these eight reviewed cases. As the majority of the reported cases of lipoma within superior central veins were incidentally found, this entity seems to be under diagnosed. Case studies often enhance the awareness about under reported conditions.

\section{CASE REPORT}

A 47-year-old afro-descendent man, presented with longstanding intermittent breathlessness associated with moderate physical efforts, but he did not seek medical attention. About 12 years ago, he was victim of an automobile accident, and a routine computerized tomography (CT) showed bilateral lung hyperdense images, considered suggestive of pulmonary fibrosis. Further transbronchial lung biopsy yielded evidence of noncaseating epithelioid granulomas, and the diagnosis of sarcoidosis was established. This condition evolved restricted to the lungs. Thereafter, he has been under continuous use of prednisone for 12 years; initially $60 \mathrm{mg}$ daily, with tapering dose until the actual schedule of $7.5 \mathrm{mg} /$ day. There was neither antecedent of low-fat diets nor use of hypolipidemic drugs. Moreover, he has been submitted to periodical clinical and thorax CT evaluations. In September 2010, the imaging studies of control incidentally revealed intraluminal polypoid image measuring $5.5 \times 2.5$ $\mathrm{x} 2.0 \mathrm{~cm}$, with origin on the axillary transition of the right brachiocephalic vein, and with caudal extremity located within the superior vena cava about $1.0 \mathrm{~cm}$ below the confluence of brachiocephalic veins (Fig. 1). The intravascular mass appeared well-defined, hypo-attenuated $(-100 \mathrm{HU})$, and without enhancement after administration of intravenous contrast, similar to normal subcutaneous fat and highly consistent with intravascular lipoma. Retrospective analysis of control CT studies contributed to confirm a similar image in the last year examination. After the diagnosis of intravascular lipoma, anticoagulant drugs were administered; initially enoxaparin, which was followed by warfarin (5mg daily). He denied alcohol or tobacco use as well as antecedent of diabetes or thoracic trauma. On admission, his general condition was good, without fever, cyanosis or edema; but he was obese (BMI: $30.46 \mathrm{Kg} / \mathrm{m}^{2}$ ) with centripetal fat distribution indicative of secondary Cushing syndrome. Except for bilateral sparse crackles and wheezing on the chest, physical examination was unremarkable. Worth of note, cutaneous lipomas were not detected by physical examination as well as by imaging study. Laboratory data were unremarkable, including thyroid tests and lipidogram (cholesterol: 121 $\mathrm{mg} / \mathrm{dl}$; triglycerides: $91 \mathrm{mg} / \mathrm{dl}$; HDL: $33 \mathrm{mg} / \mathrm{dl}$; LDL: $70 \mathrm{mg} / \mathrm{dl}$; and VLDL: $18 \mathrm{mg} / \mathrm{dl})$. Surgical excision of this lipoma was not an immediate option because the patient was asymptomatic, and without any evidence of obstruction or suggestive signs of malignancy. The patient was informed about the advantages of surgical treatment, but he refused any invasive procedure and opted for a conservative watchful management. The hypothesis of adverse effect of chronic corticosteroid use in the genesis of centripetal obesity, in addition to the intravenous lipoma, led us to change the schedule of prednisone by methotrexate. After three years of close ambulatory surveillance, he follows an asymptomatic course and the imaging exams of control have not detected any remarkable change in the mass volume. 


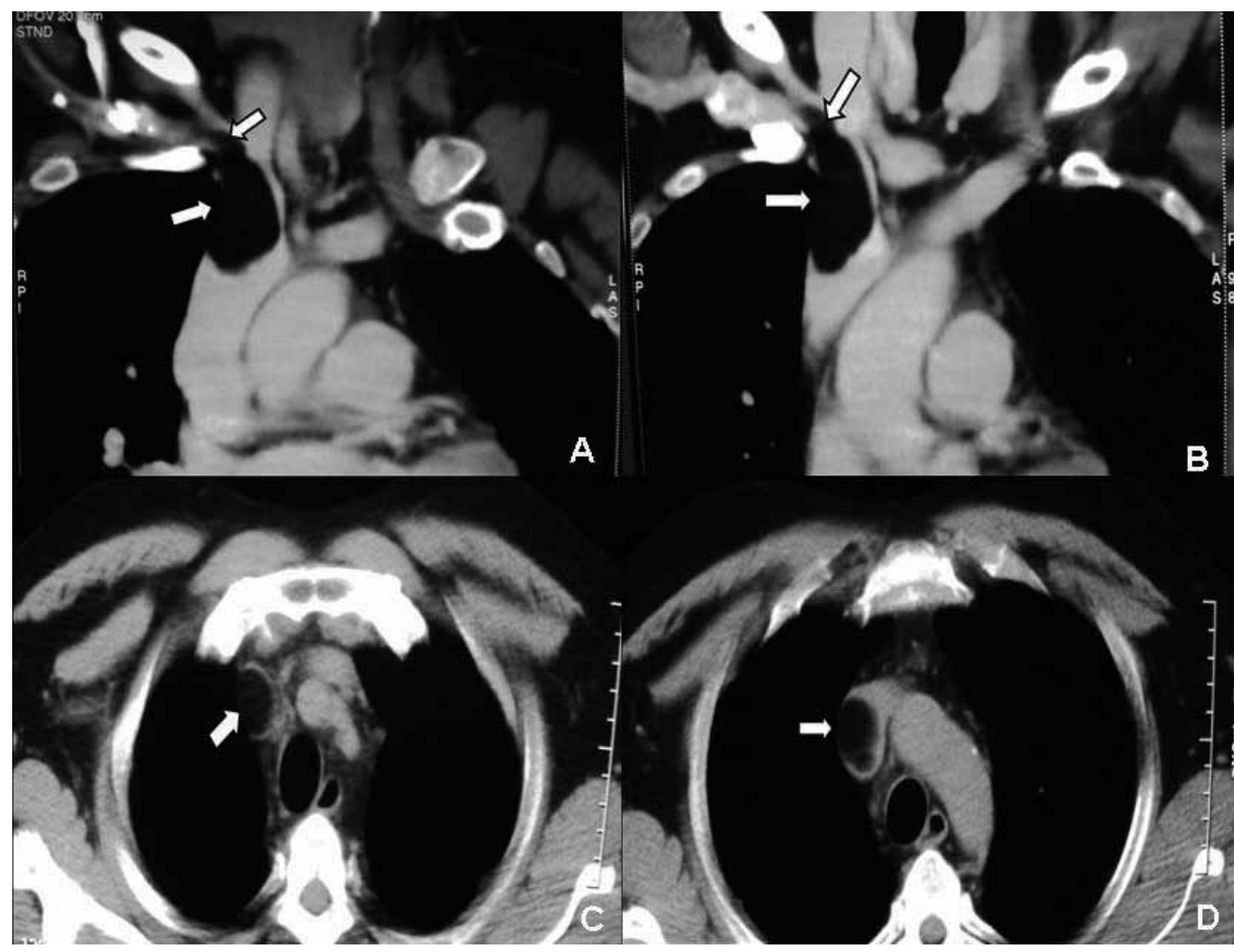

Figure 1. CT of thorax showing intraluminal polypoid image (arrows) with origin on the right brachiocephalic vein (A and B), and with caudal extremity ( $C$ and D) located within the superior vena cava. The intravascular lesion appeared as well-defined hypo-attenuating (-100 HU) mass, without enhancement after intravenous contrast administration.

\section{SHORT LITERATURE REVIEW}

A literature search was performed in MEDLINE (1966 to 2010) and EMBASE (1980 to 2011), with the keywords intravascular, intravenous, lipoma, corticosteroid, and sarcoidosis. Data of the patient here reported were compared with eight previous descriptions (Table 1$)^{4-11}$. Mean age of the reviewed patients was $55 \pm 9.9$ years, with median age of 55 (42-73) years, and $75 \%$ of them were males. Imaging studies revealed the following distribution of lipoma: superior vena cava (6/8) $75 \%)$, right brachiocephalic vein (5/8) $62.5 \%$, and right subclavian vein $(3 / 8) 37.5 \%$. Surgical procedure to remove intravenous lipoma was not performed in three of these cases ${ }^{6,8,9}$. Interestingly, obstructive symptoms related to the intravenous tumor were observed in a unique case, and were manifested by mid-facial and right hand swelling ${ }^{11}$. Worth of note, histological diagnosis confirmation was not obtained in (3/8) $37.5 \%$ of the patients. Moreover, any antecedent of corticotherapy was reported in this reviewed group of patients. 
Table 1. Data of nine patients showing intravascular lipomas within superior central veins

\begin{tabular}{l|c|c|c|cc}
\multicolumn{1}{c}{ Authors (year) } & Patients/ ages & \multicolumn{1}{c}{ Symptoms } & \multicolumn{2}{c}{ Locations } & Surgery \\
\hline Vinnicombe S et al. ${ }^{11}(1994)$ & Female/ 42 years & Swelling & RBV, SVC & Yes \\
Thorogood SV et al. ${ }^{9}(1996)$ & Male/ 73 years & Absent & RBV, SVC & No \\
Trabut JB et al. ${ }^{10}(1999)$ & Male/ 55 years & Absent & SVC & Yes \\
Lomeo A et al. ${ }^{5}(2007)$ & Male/ 60 years & Absent & RSV, SVC & Yes \\
Moore FO et al. ${ }^{6}(2008)$ & Male/ 58 years & Absent & RBV & No \\
Ryu SR et al. ${ }^{8}(2009)$ & Male/ 47 years & Absent & RSV, RBV & No \\
Mordant P et al. ${ }^{7}(2010)$ & Female/ 55 years & Absent & RSV, RBV, SVC & Yes \\
Bravi MC et al. ${ }^{4}(2011)$ & Male/ 63 years & Absent & SVC & Yes \\
Santos LAM et al. (2012)* & Male/ 47 years & Absent & RSV, RBV, SVC & No \\
\hline
\end{tabular}

RBV: right brachiocephalic vein; RSV: right subclavian vein; SVC: superior vena cava; $\left({ }^{*}\right)$ : The present case study.

\section{DISCUSSION}

In the present case study, the patient was submitted to a chronic use of prednisone to treat lung sarcoidosis and developed centripetal distribution of body fat. The diagnosis of intravascular lipoma was incidental, during a routine control of sarcoidosis by CT of thorax done in 2009. Retrospective analysis of CT images from an exam done in 2008 disclosed an unchanged lesion. Accordingly to literature, both superficial and internal lipomas may develop in patients submitted to longstanding use of systemic corticosteroids $^{3}$. Mediastinal and epidural spaces are the most common localizations of these lipomas. Intravascular lipoma is a very rare condition with unclear physiopathology mechanism, which includes both individual tissue sensibility and different number of cellular receptors to corticosteroids $^{3}$. Although the venous media layer has few adipocytes ${ }^{5}$, intravenous lipoma may developed either from the vein wall (intraluminal origin) or by invagination of adjacent adipose tissue (extraluminal origin $)^{5,6,12,13}$. Differential diagnosis includes both benign (hemangioma, thombosis, leiomyoma,) and malignant (leiomyosarcoma, angiosarcoma) conditions $\mathbf{s}^{6,9,13,14}$. A possible concern could be about the absence of surgical findings; however, a densitometric study of CT scans well demonstrated an homogenous mass with hypo attenuation and characteristics of normal fatty tissue ${ }^{4}$. There was no enhancement after injection of contrast ${ }^{12-14}$, and the volume of the mass did not change during four years of control by comparative imaging studies. Diagnosis of intravenous lipoma, and lipomas from diverse locations have been similarly characterized with base on typical images of CT and magnetic resonance studies ${ }^{4,6-9,12-14}$. Moreover, the lack of histopathology data in the case of this patient seems justified ${ }^{6,9,12}$, and does not differ of three of the case studies that were previously published ${ }^{6,8,9}$. Our patient was treated with $20 \mathrm{mg} /$ day of prednisone for more than a decade, which is a very long period if compared with the estimated time of four months $(15 \mathrm{mg} /$ day) necessary for development of secondary epidural lipomas ${ }^{3}$. He was obese and had secondary Cushing syndrome, two conditions that have been associated with the origin of epidural lipomas ${ }^{3}$. Main factors involved in the genesis of corticoid-induced epidural lipomas include hypothyroidism, and Paget disease of bone ${ }^{3}$. Otherwise, intravascular lipomas are related to liver cirrhosis, hepatic tumors, renal angiomyolipoma, direct vessel injury and obesity $^{12,13}$. The probable causal relationship between chronic use of corticoster- 
oids and the origin of lipoma in the patient here described also differs from the eight similar cases of lipomas found within the superior vena cava, and the brachiocephalic or the subclavian veins ${ }^{4-11}$. Worth of note, corticosteroids were not utilized by the individuals from that select group. Corticosteroid-induced dyslipidemia can play a role in the genesis of lipomatosis; but the data of lipidogram were unremarkable in the present case and this possibility was ruled out. Alternative factors as thyroid, bone, liver and renal diseases or trauma were discarded too. At the best of our knowledge, the case study here described is the first example of intravenous lipoma concomitant with the chronic use of prednisone to treat lung sarcoidosis. Montoriol et al. (2010) first described a 26-year-old man with epidural lipomatosis and Cushing syndrome secondary to longterm treatment of systemic sarcoidosis ${ }^{3}$. Interestingly, there was no dyslipidemia in their young patient, like was observed in the present case study. The physiopathology of intravenous lipoma associated or not with corticotherapy remains unclear due to the scarce literature about this condition, and experimental data are lacking. So, one can hypothesize the still elusive role of some immunologic phenomenon associated with sarcoidosis ${ }^{1,2}$, which could affect the structural components of the vessel wall. Indeed, recent studies about vascular wall-resident multipotent stem cells with mesenchymal stem cell characteristics have confirmed their potential differentiation into adipocytes ${ }^{15}$. Although the pathogenesis of lipoma is not well understood, literature data confirm accelerated adipogenesis plus nonenhanced apoptosis associated with proliferating adipose-derived stem/progenitor/stromal cells (ASCs) ${ }^{16}$. An additional concern is about the role of corticosteroids, which could not be determinant in the genesis of epidural or intravenous lipomas seen in sarcoidosis. Hypothetically, this chronic disorder could constitute the main causal factor of such lipomas, and the coexistence of long-term corticotherapy with the intravenous lipoma might be casual.
Further research is needed to clear the relationship between chronic conditions treated with corticosteroids and the development of lipomas within major central veins.

\section{REFERENCES}

1. Ghaddar RK, Muzaffar TH. Pulmonary sarcoidosis and autoimmune hemolytic anemia: possible common immune pathogenesis. Arch Iran Med 2011; 14: 146-148.

2. Toussirot E, Gaugler B, Bouhaddi M, Nguyen NU, SaAs P, Dumoulin G. Elevated adiponectin serum levels in women with systemic autoimmune diseases. Mediators Inflamm 2010; 2010: 938408. Epub 2010 Dec 26.

3. Montoriol PF, Da Ines D, Bailly A, Garcier JM. Steroid-induced epidural lipomatosis in a patient with sarcoidosis. J Radiol 2010; 91: 511513.

4. Bravi MC, Salvadei S, Scarponi P, Loforte A, MuSUMECI F, GASBARRONE L. Intravascular lipoma of the superior vena cava. Intern Emerg Med 2012; 7: 79-81.

5. Lomeo A, D'arrigo G, Scolaro A, Mudanò M, MoNEA MC, MAUCERI G et al. A case of intra and extra-vascular lipoma of the subclavian vein. EJVES Extra 2007; 13: 37-39.

6. Moore FO, Petersen SR, Norwood SH. Intravascular lipoma of the right innominate vein in a trauma patient. J Am Coll Surg 2008; 207: 139.

7. Mordant P, Mercier O, Fadel E, Muniappan A, FaBRE D, Chataigner O et al. Surgical resection of an intravascular superior vena cava primary lipoma. J Thorac Cardiovasc Surg 2010; 140: 1437-1438.

8. Ryu SR, Park JY, Ryu YS, Yu YH, Yang DJ, LeE $\mathrm{BH}$ et al. Intravascular lipoma of the right subclavian vein. Tuberc Respir Dis 2009; 67: 154-157.

9. Thorogood SY, MASKELl GF. Case report: intravascular lipoma of the superior vena cavaCT and MRI appearances. Br J Radiol 1996; 69: 963-964.

10. Trabut JB, Duong Van Huyen JP, Artru B, BruNEVAL P. Intravascular lipoma of the superior vena cava. Ann Pathol 1999; 19: 529-531.

11. Vinnicombe S, Wilson AG, Morgan R, Saunders $K$. Intravascular lipoma of the superior vena cava: CT features. J Comput Assist Tomogr 1994; 18: 824-827.

12. Grassi R, Di Mizio R, Barberi A, Severini S, Del Vecchio A, Cappabianca S. Case report. Ultra- 
sound and CT findings in lipoma of the inferior vena cava. Br J Radiol 2002; 75: 69-71.

13. Perry JN, Williams MP, Dubbins PA, Farrow R. Lipomata of the inferior vena cava: a normal variant? Clin Radiol 1994; 49: 341-342.

14. Karlo CA, Stolzmann P, Frauenfelder T, Donati OF, LeschKa S. Computed tomography imaging of subpleural lipoma in two men: two case reports. J Med Case Reports 2010; 4: 380 .
15. Klein D, Weisshardt P, KLEFF V, Jastrow H, JAков HG, ERGÜN S. Vascular wall-resident CD44+ multipotent stem cells give rise to pericytes and smooth muscle cells and contribute to new vessel maturation. PLoS One 2011; 6: e20540.

16. Suga H, Eto H, Inoue $\mathrm{K}$, Aor $\mathrm{N}$, Kato $\mathrm{H}$, Araki J et al. Cellular and molecular features of lipoma tissue: comparison with normal adipose tissue. Br J Dermatol 2009; 161: 819-825. 